\title{
PENGUATAN PENEGAKAN HUKUM HAK KEKAYAAN INTELEKTUAL (Studi Kritis terhadap Peran Pendidikan Kewarganegaraan)
}

\author{
Triyanto \\ Fakultas Keguruan Ilmu Pendidikan Univeritas Sebelas Maret \\ E-mail: try_uns@yahoo.com
}

\begin{abstract}
This study discusses the role of Civic/Citizenship Education (CE) in strengthening IPR law enforcement. This study aimed to identify: (1) the effectiveness of IPR law enforcement has done; (2) the constraints; (3) the efforts to overcome obstacles; (4) CE Model of IPR National Team; (5) weakness of the CE model of IPR National Team; (6) efforts to overcome the weaknesses of the CE model of IPR National Team; and (7) the role of CE to strengthen IPR law enforcement.

The research used a qualitative method. The samples of the research were gathered by using purposive sampling and snowball sampling techniques. Its data were gathered through library research, in-depth interview, observation, and focus group discussion. They were then analyzed by using interactive (Miles \& Huberman, 1984: 23) and bottom up (Creswell, 2008: 244) models of analysis.

The results of the research show that: (1) the law enforcement for the IPR has not been effective; (2) The law enforcement for the IPR has encountered some constraints caused by the factors of law enforcement apparatus, community, and holders of the IPR; (3) The efforts to overcome the constraints of IPR law enforcement needs to be done in a systematic approach involving educational approach; (4) CE Model of IPR National Team can be seem in preemptive and preventive actions; (5) the weakness of the CE Model of IPR National Team is the absence of IPR education approach for early childhood; (6) The IPR education program for early childhood can be used to overcome the weakness, with the cooperation of private funding and the use of CSR; (7) In conclusion, CE can be used as means of IPR education through the implantation of the values of honesty, respect and appreciation of one's rights (IPR) for early childhood.
\end{abstract}

Keywords: Improving the Law Enforcement, Intellectual Property Rights, and, Civic/Citizenship Education

\begin{abstract}
Abstrak
Tujuan dari penelitian ini adalah untuk mengetahui peran Pendidikan Kewarganegaraan (PKn) dalam memperkuat penegakan hukum Hak Kekayaan Intelektual (HKI). Penelitian ini menggunakan metode kualitatif. Pengambilan sampel menggunakan metode purposive sampling and snowball sampling. Data dikumpulkan dengan menggunakan metode studi pustaka, wawancara, observasi dan focus group discussion (FGD). Data kemudian dianalisis menggunakan model analisis interaktif dan bottom up. Hasil penelitian menunjukkan bahwa PKn dapat menjadi wahana pendidikan kesadaran HKI melalui internalisasi nilai-nilai yang terkandung dalam PKn dan HKI. Kesimpulannya, PKn dapat digunakan sebagai sarana pendidikan kesadaran HKI melalui penanaman nilai-nilai kejujuran, penghormatan dan penghargaan terhadap hak orang lain sejak usia dini.
\end{abstract}

Kata Kunci: Penegakan Hukum, HKI, PKn

\section{A. Pendahuluan \\ Penghormatan dan penghargaan terhadap hak-hak kekayaan intelektual (intellectual property rights) merupakan salah}

satu ciri masyarakat yang maju dan berkeadaban. Cita masyarakat ideal (civic ideal) mengharapkan agar setiap warga negara (citizen) saling menghormati dan menghargai hak-hak 
(rights) sesama warga negara. Dalam suatu civic ideal tidak dibenarkan ada ruang terhadap segala bentuk pelanggaran hak kekayaan intelektual (HKI) karena hal tersebut dapat menghambat upaya pembentukan masyarakat yang adil dan beradab (civil society). Oleh karenanya, segala bentuk kreativitas intelektual individu perlu mendapat penghormatan dan penghargaan baik secara moral maupun ekonomi.

Sejauh ini penegakan hukum HKI lebih banyak dilakukan secara represif dengan melakukan rasia (operasi rahasia), sweeping, penggrebekan, penyitaan, dan menghukum orang yang melakukan pelanggaran HKI. Cara ini terbukti belum efektif karena faktanya tingkat pelanggaran HKI terus meningkat dari tahun ke tahun. Adapun upaya-upaya pre-emtif dan preventif yang telah dilakukan belum menunjukkan hasil yang signifikan.

Pelanggaran HKI berupa pembajakan, penjiplakan, peniruan, pemalsuan, pemakain tanpa ijin dan sejenisnya masih belum dianggap sebagai kejahatan yang serius dibanding dengan kejahatan lainnya sehingga masih banyak terjadi pelanggaran. Produk bajakan diedarkan secara terbuka dan terang-terangan tanpa adanya rasa ketakutan melanggar hukum. Pelanggaranpelanggaran tersebut selain disebabkan oleh adanya peluang yang ditawarkan oleh kemajuan teknologi informasi dan komunikasi juga kurangnya pemahaman dan kesadaran hukum masyarakat, khususnya bidang HKI (Riswandi \& Syamsudin, 2005: 38).

Sebenarnya Indonesia telah mengatur perlindungan hukum terhadap HKI dalam berbagai peraturan perundang-undangan. Undang-Undang HKI juga telah memberikan sanksi pidana maupun perdata terhadap segala bentuk pelanggaran HKI. Pada kenyataannya, berbagai peraturan tersebut belum cukup efektif untuk memberikan perlindungan HKI dan meningkatkan kesadaran masyarakat tentang penghormatan dan penghargaan terhadap HKI. Buktinya, pelanggaran HKI masih tinggi, dilakukan secara terang-terangan, dan kerugian yang ditimbulkannya juga semakin meningkat.

Peningkatan kesadaran (awareness) HKI tidak cukup hanya melalui pendekatan represif karena pelanggaran HKI terkait erat dengan karakter suatu masyarakat. Oleh karenanya diperlukan pendekatan lain berupa pendekatan pendidikan. Artikel ini membahas pendekatan pre-emtif dan preventif khususnya Pendidikan Kewarganegaraan (PKn) untuk memperkuat penegakan hukum HKI di Indonesia.
Pendidikan Kewarganegaraan pada hakikatnya merupakan pendidikan yang mengarah pada terbentuknya warga negara yang baik dan bertanggung jawab. Secara konseptualepistemologis, PKn memiliki misi menumbuhkan potensi individu agar memiliki pengetahuan, sikap, dan keterampilan sebagai warga negara yang berwatak dan berperadaban baik (Winataputra, 2001: 131).

Pendidikan Kewarganegaraan merupakan salah watu wujud dari pendidikan karakter yang mengajarkan etika personal dan nilai-nilai kebajikan (Best, 1960; Winataputra, 2001: 131). Pendidikan Kewarganegaraan merupakan sebuah proses untuk membentuk karakter individu menjadi warga negara yang baik dan cerdas atau smart and good citizen (Cogan and Derricot, 1998: 2). Pendidikan Kewarganegaraan dapat dijadikan sebagai sarana pembangunan karakter bangsa (nation character building) (Sapriya, 2005: 4). Dalam konteks ini PKn sangat relevan digunakan sebagai wahana peningkatan kesadaran HKI masyarakat guna memperkuat penegakan hukum HKI di Indonesia.

Secara khusus artikel ini mengkaji efektivitas penegakan hukum HKI dan peran PKn dalam penguatan penegakan hukum HKI di Indonesia. Tulisan ini merupakan hasil penelitian Disertasi Program Doktor (S3) Program Studi Pendidikan Kewarganegaraan (PKn) Sekolah Pascasarjana Universitas Pendidikan Indonesia.

\section{B. Metode Penelitian}

Penelitian ini menggunakan metode kualitatif. Pelaksanaan penelitian ini terjadi secara ilmiah, apa adanya, dalam situasi normal yang tidak dimanipulasi keadaan maupun kondisinya, menekankan pada deskripsi secara alami. Pengambilan data atau penjaringan fenomena dilakukan dari keadaan sewajarnya ini disebut pengambilan data secara alamiah (natural). Oleh sebab itu penelitian ini melibatkan peneliti secara langsung di lapangan (Lincoln \& Guba, 1985: 97).

Peneliti melakukan penelitian dengan terjun langsung serta membaur ke masyarakat yang terlibat dalam pembajakan HKI terutama di Solo, Yogyakarta, dan Bandung. Peneliti juga mendatangi berbagai institusi/pihak yang terlibat langsung dalam penanggulangan pembajakan HKI, yaitu:

1. Direktoral Jenderal Hak Kekayaan Intelektual, Kementerian Hukum dan HAM beralamat di Jl. Daan Mogot Km.24 
Tangerang Banten (Sekretariat Timnas HKI).

2. Direktorat Industri dan Perdagangan, Badan Reserse Kriminal (Bareskrim) Markas Besar Kepolisian Republik Indonesia, beralamat di Jl. Trunojoyo No.3 Jakarta.

3. Indonesian Intellectual Property Academy (IIPA), Fakultas Hukum, Universitas Indonesia, Beralamat di Depok, Jawa Barat.

4. Firma Hukum Soemadipradja \& Taher, beralamat di Jl. Jenderal Sudirman No. 28 Jakarta 10210.

5. Asosiasi Industri Rekaman Indonesia (ASIRI), beralamat di Jl. Gatot Subroto Kav.72 Jakarta.

Sampel/subyek penelitian ini terdiri dari berbagai pihak seperti akademisi, praktisi, pejabat, produsen, dan konsumen yang terlibat langsung dalam penegakan hukum HKI. Secara lebih spesifik subyek/sampel penelitian yang terlibat dalam penelitian ini adalah terdiri atas:

1. Direktur Jenderal Hak Kekayaan Intelektual, Kementerian Hukum dan HAM, beserta staf dan jajarannya yang mengurusi penegakan hukum HKI.

2. Prof. Dr. Agus Sadjono selaku guru besar ilmu HKI dari Universitas Pendidikan Indonesia

3. Kompol Pratomo Satriawan, SIK, selaku Penyidik Subdit I Industri \& Perdagangan Mabes Polri

4. Justisiari P. Kusumah, SH., selaku Ketua Umum Asosiasi Konsultan Hukum HKI Indonesia.

5. Marulam J. Hutauruk, SH., selaku General Manager Asosiasi Industri Rekaman Indonesia (ASIRI).

6. Para produsen dan konsumen barang bajakan sebagaimana tertulis dalam transkip wawancara dan catatan lapangan (field notes).

Metode pengumpulan data dan instrumen yang digunakan dalam penelitian ini terdiri atas: Studi Pustaka (Literature Review), Observasi (Observation), Wawancara (Interview), dan Diskusi Kelompok Terfokus (Focus Group Discussion). Penelitian ini akan menggunakan dua model teknik analisis yaitu dari Miles \& Huberman (1984: 23) dan Creswell (2008: 244).

\section{Hasil Penelitian dan Pembahasan \\ 1. Penegakan Hukum}

Penegakan hukum merupakan rangkaian proses untuk menjabarkan nilai, ide, cita yang cukup abstrak menjadi tujuan hukum.
Tujuan hukum atau cita hukum memuat nilainilai moral, seperti keadilan dan kebenaran. Nilai-nilai tersebut harus mampu diwujudkan dalam realitas nyata. Eksistensi hukum diakui apabila nilai-nilai moral yang terkandung dalam hukum tersebut mampu diimplementasikan atau tidak (Ufran, 2009: vii).

Pada hakikatnya hukum mengandung ide atau konsep-konsep yang dapat digolongkan sebagai sesuatu yang abstrak. Kelompok abstrak termasuk ide tentang keadilan, kepastian hukum dan kemanfaatan (Radburg, 1961: 36). Apabila berbicara tentang penegakan hukum, maka pada hakikatnya berbicara tentang penegakan ide-ide serta konsep-konsep yang notabene adalah abstrak tersebut. Dirumuskan secara lain, penegakan hukum merupakan suatu usaha untuk mewujudkan ide-ide tersebut menjadi kenyataan. Proses perwujudan ide-ide tersebut merupakan hakikat dari penegakan hukum (Rahardjo, 2009: 12).

Penegakan hukum sebagai sarana untuk mencapai tujuan hukum, maka sudah semestinya seluruh energi dikerahkan agar hukum mampu bekerja untuk mewujudkan nilai-nilai moral dalam hukum. Kegagalan hukum untuk mewujudkan nilai hukum tersebut merupakan ancaman bahaya akan bangkrutnya hukum yang ada. Hukum yang miskin terhadap implementasi nilai-nilai moral akan berjarak serta terisolasi dari masyarakatnya. Keberhasilan penegakan hukum menentukan serta menjadi barometer legitimasi hukum di tengah-tengah realitas sosialnya (Ufran, 2009: vii-viii).

Menurut kajian normatif penegakan hukum adalah suatu tindakan yang pasti yaitu menerapkan hukum terhadap suatu kejadian, yang dapat diibaratkan menarik garis lurus antara dua titik. Dalam ilmu hukum cara seperti itu disebut sebagai model mesin otomat dan pekerjaan menegakan hukum menjadi aktivitas subsumsi otomat. Disini hukum dilihat sebagai variabel yang jelas dan pasti dan terlihat sangat sederhana (Rahardjo, 2002: 172). Dalam kenyataannya tidak sesederhana itu, melainkan yang terjadi penegakan hukum itu mengandung pilihan dan kemungkinan, oleh karena dihadapkan kepada kenyataan yang kompleks. Dalam ilmu hukum normatif kompleksitas tersebut diabaikan, sedangkan sosiologi hukum sebagai ilmu empirik sama sekali tidak dapat mengabaikannya.

Menurut Soerjono Soekanto (1993: 5), secara konsepsional, penegakan hukum adalah kegiatan menyerasikan hubungan nilai-nilai yang terjabarkan dalam kaidah-kaidah yang mantab 
dan mengejawantah dan sikap tindak sebagai rangkaian penjabaran nilai tahap akhir, untuk menciptakan, memelihara dan mempertahankan kedamaian pergaulan hidup.

Selanjutnya Satjipto Raharjo (1998: 24) berpendapat bahwa unsur-unsur yang terlibat dalam proses penegakan hukum dibagi dalam dua golongan besar, yaitu unsur-unsur yang mempunyai tingkat keterlibatan yang agak jauh dan yang dekat. Sebagai contoh unsur yang mempunyai keterlibatan yang dekat dengan proses penegakan hukum adalah legislatif atau pembuat Undang-Undang dan polisi, sedang unsur pribadi dan sosial mempunyai keterlibatan yang jauh.

Hal ini dapat dipahami karena legislatif adalah badan yang memproduksi peraturan, sedang polisi adalah badan yang melaksanakan peraturan sehingga mempunyai hubungan yang sangat dekat dengan proses penegakan hukum, sedang masyarakat adalah obyek yang terkena peraturan sehingga wajar apabila keterlibatannya dengan proses penegakan hukum terlihat lebih jauh. Oleh karena itu menurut Satjipto Raharjo, penegakan hukum adalah suatu proses untuk mewujudkan keinginan-keinginan hukum menjadi kenyataan. Pengertian keinginankeinginan hukum disini adalah pikiran-pikiran badan pembuat Undang-Undang yang dirumuskan dalam peraturan-peraturan hukum itu. Keberhasilan dari proses penegakan hukum itu sangat tergantung oleh para pejabat penegak hukum itu sendiri (Rahardjo, 1998: 24).

Penegakan hukum dilihat dari kacamata normatif memang merupakan permasalahan yang sangat sederhana, tetapi bila dilihat dari kacamata sosiologis maka penegakan hukum merupakan proses yang panjang dan merupakan suatu perjuangan. Sebagaimana dikemukakan oleh Barda Nawawi Arief (2001: 2), bahwa penegakan hukum dan keadilan merupakan serangkaian proses yang cukup panjang dan dapat melibatkan berbagai kewenangan instansi aparat penegak hukum lainnya (di bidang penegakan hukum pidana melibatkan aparat penyidik/kepolisian, aparat penuntut umum kejaksaan, aparat pengadilan, dan aparat pelaksana pidana).

\section{2) mengatakan:}

Selanjutnya Leden Marpaung (1997:

"Penegakan hukum tidak berlangsung dalam suasana vakum atau kekosongan sosial. Yang dimaksud dengan kekosongan sosial adalah tiadanya proses-proses di luar hukum yang secara bersamaan berlangsung dalam masyarakat. Proses-proses tersebut adalah seperti ekonomi dan politik. Penegakan hukum berlangsung di tengah-tengah berjalannya proses-proses tersebut. Dengan dikeluarkanya Undang-Undang misalnya maka tidak sim-salabim lalu segalanya menjadi persis seperti dikehendaki oleh Undang-Undang itu. Hubungan kompetitif, tarik menarik dan dorong mendorong antara hukum dan bidang serta proses lain di luarnya tetap saja terjadi”.

Menurut Marc Galanter (Rahardjo, 1998:1) mengatakan:

"bahwa penegakan hukum tidak sesederhana yang kita duga, melainkan bahwa penegakan hukum itu mengandung pilihan dan kemungkinan, oleh karena dihadapkan kepada kenyataan kompleks. Dalam ilmu hukum normatif kompleksitas itu diabaikan, sedangkan sebagai ilmu yang empirik tidak dapat mengabaikannya. Sosiologi hukum berangkat dari kenyataan di lapangan, yaitu melihat berbagai kenyataan, kompleksitas, yang ada dalam masyarakat dan bagaimana kenyataan itu membentuk maksud dengan melihat hukum dari (from the other end of the telescope) "ujung yang lain dari teleskop". Oleh karena memasukan kompleksitas tersebut ke dalam pemahaman dan analisisnya, maka dalam sosiologi hukum, penegakan hukum itu tidak bersifat logis universal, melainkan variabel”.

Sebagaimana telah dikemukakan sebelumnya bahwa penegakan hukum mengandung pilihan dan kemungkinan, oleh karenanya dihadapkan pada masalah yang kompleks, baik pada tahap aplikasinya maupun pada tahap formulasi. Karena kondisinya tidak steril maka dalam proses penegakannya juga dapat dihinggapi berbagai permasalahan baik yang positif maupun negatif, dipengaruhi oleh berbagai kepentingan baik kepentingan pembuat Undang-Undang, kepentingan pelaksana Undang-Undang, dan kepentingan masyarakat yang terkena Undang-Undang. Faktor kepentingan dari unsur-unsur yang terdapat di dalam proses penegakan hukum tampaknya memegang peran dominan, sebagaimana penelitian Stewart Macaulay tentang penegakan hukum kontrak yang telah dibuat sendiri oleh para pelaku justru banyak yang dikesampingkan, hubungan bisnis antara para pelaku tidak selalu didasarkan pada kontrak yang telah dibuat sendiri. Hubungan-hubungan yang seharusnya 
bersifat kontraktual tetapi ternyata telah menjadi non kontraktual, karena ternyata yang bersifat non kontraktual lebih menguntungkan bagi kedua belah pihak dalam melakukan hubungan bisnis (Rahardjo, 1998: 179).

Selanjutnya menurut Muladi (1995: 69) penegakan hukum sebagai suatu usaha untuk menegakkan norma-norma dan sekaligus nilainilai yang ada di belakang norma tersebut. Untuk itu, para penegak hukum harus memahami betul semangat hukum yang mendasari dibuatnya peraturan hukum yang hendak ditegakkan itu. Aparat penegak hukum harus menyadari bahwa penegakan hukum sebagai subsistem dari sistem yang lebih luas, rentan terhadap pengaruh lingkungan, seperti pengaruh perkembangan politik, ekonomi, pendidikan, globalisasi. Karena itu, pemahaman atas perlunya kebersamaan dan kerjasama antar komponen yang digambarkan sebagai pendekatan sistem dalam sistem peradilan pidana (criminal justice system) sudah seharusnya terimplementasi dalam tiap komponen atau aparat penegak hukum.

Penegakan hukum sebagai bentuk konkrit penerapan hukum sangat mempengaruhi secara nyata perasaan hukum, kepuasan hukum, manfaat hukum, kebutuhan atau keadilan hukum secara individu atau sosial. Tetapi karena penegakan hukum tidak mungkin terlepas dari aturan hukum, pelaku hukum, lingkungan tempat terjadi proses penegakan hukum, maka tidak mungkin ada pemecahan persoalan penegakan hukum apabila hanya melirik pada proses penegakan hukum, apalagi lebih terbatas pada penyelenggaraan peradilan (Manan, 2005: 4).

Selanjutnya Jimly Asshiddiqie (2008: 4) membagi pengertian penegakan hukum menjadi dua, yaitu:

a. Penegakan Hukum (law enforcement) dalam arti luas mencakup kegiatan untuk melaksanakan dan menerapkan hukum serta melakukan tindakan hukum terhadap setiap pelanggaran atau penyimpangan hukum yang dilakukan oleh subyek hukum, baik melalui prosedur peradilan ataupun melalui prosedur arbitrase dan mekanisme penyelesaian sengketa lainnya (alternative disputes or conflicts resolution). Bahkan, dalam pengertian yang lebih luas lagi, kegiatan penegakan hukum mencakup pula segala aktivitas yang dimaksudkan agar hukum sebagai perangkat kaidah normatif yang mengatur dan mengikat para subjek hukum dalam segala aspek kehidupan bermasyarakat dan bernegara benar-benar ditaati dan sungguh-sungguh dijalankan sebagaimana mestinya.

b. Penegakan hukum dalam arti sempit, mencakup kegiatan penindakan terhadap setiap pelanggaran atau penyimpangan terhadap peraturan perundang-undangan, khususnya -yang lebih sempit lagimelalui proses peradilan pidana yang melibatkan peran aparat kepolisian, kejaksaan, advokat atau pengacara, dan badanbadan peradilan.

Penelitian ini bertitik tolak dari pengertian penegakan hukum secara luas. Artinya, penegakan hukum HKI tidak sebatas rasia, penangkapan, penggrebekan dan upaya represif lain, akan tetapi juga termasuk berbagai upaya pre-emtif berwujud pendidikan maupun preventif berwujud sosialisasi peraturan.

Masalah penegakan hukum merupakan masalah yang tidak sederhana, bukan saja karena kompleksitas sistem hukum itu sendiri, tetapi juga rumitnya jalinan hubungan antara sistem hukum dengan sistem sosial, politik, ekonomi dan budaya masyarakat. Sebagai suatu proses, penegakan hukum pada hakikatnya merupakan variabel yang mempunyai korelasi dan interdependensi dengan faktor-faktor lain (Ufran, 2009: viii).

Menurut Lawrence M. Friedman (2001: 7), ada beberapa faktor yang terkait yang menentukan proses penegakan hukum yaitu: komponen subtansi, struktural dan kultural. Kesemua faktor tersebut akan sangat menentukan proses penegakan hukum dalam masyarakat dan tidak dapat dinafikkan satu dengan lainnya. Kegagalan pada salah satu komponen akan berimbas pada faktor yang lainnya. Menurut Muladi (1995: 2) ketiga komponen ini harus ada sinkronikasi atau keserempakan dan keselarasan yang dapat dibedakan dalam:

a. Sinkronisasi substansial (subtansial syncronization) yaitu keserempakan dan keselarasan yang bersifat vertikal dan horizontal dalam kaitannya dengan hukum positif.

b. Sinkronisasi struktural (structural syncronization) yaitu keserempakan dan keselarasan dalam kerangka hubungan antarlembaga penegak hukum.

c. Sinkronisasi kultural (cultural syncronization) yaitu keserempakan dan keselarasan dalam menghayati pandanganpandangan, sikap-sikap dan falsafah yangs secara menyeluruh mendasari jalanya sistem peradilan. 
Subtansi adalah aturan, norma, dan pola perilaku nyata manusia yang berada dalam sistem itu. Substansi berarti produk yang dihasilkan oleh orang yang berada di dalam sistem hukum itu, keputusan atau aturan baru yang mereka keluarkan. Substansi punya peran penting dalam menggerakkan kinerja organisasi, sebagai pedoman, patokan dan petunjuk arah. Struktur adalah kerangka atau bagian yang tetap bertahan, bagian yang memberi semacam bentuk dan batasan terhadap keseluruhan sistem. Struktur penegakan hukum mencakup kepolisian, kejaksaan, kehakiman, advokat, lembaga peradilan dan pemasyarakatan. Kultur atau budaya merupakan sikap manusia terhadap hukum dan sistem hukum, kepercayaan, nilai, pemikiran serta harapannya. (Friedman, 2001: 78).

\section{Pendidikan Kewarganegaraan}

Dalam beberapa literatur ditemukan bebarapa istilah seperti: "Civics", "Civic Education", dan "Citizenship Education". Ketiganya sering digunakan secara bertukar pakai (interchangeably) meskipun sebenarnya mempunyai makna yang berbeda. Secara historis-epistemologis, Amerika Serikat (AS) dapat dicatat sebagai negara perintis kegiatan akademis dan kurikuler pengembangan konsep dan paradigma "citizenship education" dan "civic education" dimana pada tahun 1880-an di AS mulai diperkenalkan mata pelajaran "Civics" sebagai mata pelajaran mengenai pemerintahan (Allen, 1960; Winataputra, 2001: 126).

Pada tahun 1900-an berkembang mata pelajaran "Civics" yang diisi dengan materi mengenai struktur pemerintahan negara bagian dan federal. Hingga tahun 1920-an istilah "Civics" telah digunakan untuk menunjuk bidang pengajaran yang lebih khusus, yakni "vocational civics, community civics dan economic civics". "Civics" pada dasarnya berkenaan dengan pembahasan mengenai pemerintahan demokrasi dalam teori dan praktik. Sedangkan istilah "civic education" menurut Manohey (Somantri, 1973: 8) merupakan suatu proses pendidikan yang mencakup proses pembelajaran semua mata pelajaran, kegiatan siswa, proses administrasi, dan pembinaan dalam upaya mengembangkan perilaku warga negara yang baik (Gross and Zeleny, 1958: 247).

Istilah "citizenship education" menunjuk suatu bentuk "character education" atau pendidikan karakter/watak (Best, 1960; Winataputra, 2001: 127). Allen (1960: 11) melihat "citizenship education" lebih luas lagi, yakni sebagai produk dari keseluruhan program pendidikan persekolahan, dimana mata pelajaran "civics" merupakan unsur yang paling utama dalam upaya mengembangkan warga negara yang baik. Sejalan dengan pendapat tersebut, The National Council for the Social Studies atau NCCS (Somantri, 1972: 9), menekankan bahwa "citizenship education" sesungguhnya mencakup "all positive influence coming from formal and informal education" atau segala macam dampak (positif) yang diperoleh baik dari sekolah formal maupun informal.

Jadi istilah "civics dan civic education" cenderung digunakan untuk mata pelajaran di sekolah yang memiliki tujuan utama mengembangkan siswa sebagai warga negara yang cerdas dan baik. Sedangkan "citizenship education" lebih cenderung digunakan dalam visi yang lebih luas untuk menunjukkan "instructional effects" dan "nurturant effect" dari keseluruhan proses pendidikan terhadap pembentukan karakter individu sebagai warga negara yang cerdas dan baik (Winataputra, 2001: 127).

Pengertian dan ruang lingkup PKn sangat beragam karena masing-masing negara maupun pakar menerjemahkan PKn secara berbeda-beda. Ada yang memandang PKn dari sudut pandang ilmu secara umum dan ada pula yang memandang PKn sebagai suatu kurikulum di sekolah.

Menurut National Council of Social Studies (NCCS) Amerika Serikat, PKn adalah proses yang meliputi semua pengaruh positif yang dimaksud untuk membentuk pandangan seorang warga negara dalam peranannya di masyarakat. PKn adalah lebih dari sekedar bidang studi. PKn mengambil bagian dari pengaruh positif dari keluarga, sekolah, dan masyarakat. Melalui PKn generasi muda dibantu untuk memahami cita-cita nasional, hal-hal yang baik diakui oleh umum, proses pemerintahan sendiri, dan dibantu untuk memahami arti kemerdekaan untuk mereka dan untuk semua manusia dan individu dan kelompok, dalam bidang kepercayaan, perdagangan, pemilu atau dalam tingkah laku sehari-hari. Mereka juga dibantu untuk memahami bermacam-macam hak kemerdekaan warga negara yang dijamin dalam konstitusi dan peraturan-peraturan lainnya dan tanggung jawab atas apa yang telah dicapainya (Cholisin, 2007: 1.8-1.9).

Dari pengertian PKn menurut NCCS, dapat dinyatakan bahwa ciri yang penting dari PKn adalah: (1) merupakan program pendidikan (proses yang meliputi pengaruh positif); (2) 
fokus materinya adalah ideologi nasional, proses pemerintahan sendiri, hak dan kewajiban asasi dan warga negara sebagaimana yang dijamin dalam konstitusi ditambah dengan pengaruh positif dari keluarga, sekolah dan masyarakat; (3) tujuannya adalah membentuk orientasi warga negara tentang peranannya dalam masyarakat (Cholisin, 2007: 1.9).

Sebuah lembaga yang bergerak di bidang kewarganegaraan (Citizenship Foundation) di Inggris (www.citizenshipfoundation.org.uk) memberikan definisi Citizenship Foundation sebagai “... about enabling people to make their own decisions and to take responsibility for their own lives and their communities". Artinya PKn merupakan suatu cara untuk menjadikan warga negara agar mampu membuat keputusan sendiri dan bertanggung jawab terhadap kehidupan dan komunitas mereka. Secara lebih sederhana dapat dikatakan bahwa "citizenship education is about helping young people understand the rights and responsibilities they have as members of society" (www.teachernet.gov.uk)

Sementara itu, menurut Parlemen Inggris (The House of Commons), Citizenship Education membahas tentang:

1) Knowledge and understanding about becoming informed citizens. Materi ini mencakup masalah: hukum dan HAM, masalah nasional, masalah regional, serta perbedaan agama dan etnis.

2) Developing skills of enquiry and communication. Misalnya: belajar untuk berpikir masalah politik, spiritual, moral, isu-isu sosial dan budaya tentang topik, menganalisis dan mencari informasi dalam masalah-masalah tersebut, serta belajar berpartisipasi dalam diskusi dan perdebatan.

3) Developing skills of participation and responsible action. Misalnya negosiasi, menentukan dan mengambil bagian secara bertanggung jawab dalam kegiatan sekolah atau komunitas, serta merefleksikan proses berpartisipasi (The House of Commons, 2006: 7).

Departemen Pendidikan Inggris (DfES) menyatakan bahwa Citizenship Education bertujuan mendorong terciptanya tiga bakat dan perilaku, yaitu:

2) Social and Moral Responsibility. Konsep ini mengajarkan tentang perlunya kepercayaan diri serta tanggung jawab secara moral dan sosial baik di dalam atau di luar kelas, baik terhadap pihak penguasa maupun antarsesama.
3) Community Involvement. Konsep ini mengajarkan tentang perlunya menggabungkan diri ke dalam masyarakat dan saling membantu satu sama lain serta mempelajari tentang keterlibatan masyarakat dan pelayanan masyarakat.

4) Political Literacy. Konsep ini mengajarkan tentang lembaga, permasalahan dan praktik demokrasi termasuk mengkaji bagaimana mengefektifkan demokrasi dalam kehidupan suatu bangsa baik secara lokal, regional dan nasional melalui pengetahuan, ketrampilan, dan nilai-nilai (The House of Commons, 2006: 7).

Hasil seminar nasional pengajaran dan pendidikan Civics di Tawangmangu (1972) memberikan pengertian PKn sebagai suatu program pendidikan yang tujuan utamanya membina warga negara yang lebih baik menurut syarat-syarat, kriteria-kriteria, ukuran-ukuran dan ketentuan-ketentuan Pembukaan UUD 1945. Bahannya diambil dari Ilmu Kewarganegaraan (IKn) termasuk kewiraan nasional, filsafat Pancasila dan filsafat pendidikan nasional, serta menuju kedudukan para warga negara yang diharapkan di masa depan (Cholisin, 2007: 1.9).

Dari pengertian PKn menurut seminar di Tawangmangu, dapat dinyatakan bahwa ciriciri PKn adalah (1) merupakan program pendidikan; (2) merupakan pengembangan dari IKn; (3) materi pokoknya adalah materi IKn ditambah dengan kewiraan nasional, filsafat Pancasila, mental Pancasila dan filsafat pendidikan nasional; (4) bersifat interdisipliner; (5) tujuannya adalah membina warga negara yang baik dan untuk masa depan sesuai dengan ketentuan Pancasila dan UUD 1945 (Cholisin, 2007: 1.9).

Menurut CICED (Center for Indonesian Civic Education), substansi dari PKn meliputi berbagai aspek yang harus dikembangkan secara konsisten sebagai pengetahuan (knowledge), sikap (attitude) dan ketrampilan (skill) yang terdiri dari (CICED, 2000: 43):

1) Principles of democracy;

2) Comprehend of state constitutions;

3) Citizen's rights and responsibility;

4) State's rule of law;

5) Good government;

6) Citizenship;

7) People sovereignty;

8) Free and fair tribune;

9) Equality and equity;

10) Justice;

11) Human rights 
12) Civilization;

13) Cultural differeces;

14) Democratic processes;

15) Citizenship activities;

16) National identity and attributes;

17) Civil society;

18) Free market economy;

19) Political processes;

20) Separation/distribution of power.

Menurut Kurikulum Tingkat Satuan Pendidikan (KTSP) 2006 (Permendiknas No.22/2006), PKn merupakan mata pelajaran yang memfokuskan pada pembentukan warga negara yang memahami dan mampu melaksanakan hak-hak dan kewajibannya untuk menjadi warga negara Indonesia yang cerdas, terampil, dan berkarakter yang diamanatkan oleh Pancasila dan UUD 1945.

Ruang lingkup mata pelajaran PKn meliputi aspek-aspek sebagai berikut.

1) Persatuan dan Kesatuan bangsa, meliputi: Hidup rukun dalam perbedaan, Cinta lingkungan, Kebanggaan sebagai bangsa Indonesia, Sumpah Pemuda, Keutuhan Negara Kesatuan Republik Indonesia, Partisipasi dalam pembelaan negara, Sikap positif terhadap Negara Kesatuan Republik Indonesia, Keterbukaan dan jaminan keadilan.

2) Norma, hukum dan peraturan, meliputi: Tertib dalam kehidupan keluarga, Tata tertib di sekolah, Norma yang berlaku di masyarakat, Peraturan-peraturan daerah, Norma-norma dalam kehidupan berbangsa dan bernegara, Sistem hukum dan peradilan nasional, Hukum dan peradilan internasional.

3) Hak asasi manusia meliputi: Hak dan kewajiban anak, Hak dan kewajiban anggota masyarakat, Instrumen nasional dan internasional HAM, Pemajuan, penghormatan dan perlindungan HAM.

4) Kebutuhan warga negara meliputi: Hidup gotong royong, Harga diri sebagai warga masyarakat, Kebebasan berorganisasi, Kemerdekaan mengeluarkan pendapat, Menghargai keputusan bersama, Prestasi diri, Persamaan kedudukan warga negara.

5) Konstitusi Negara meliputi: Proklamasi kemerdekaan dan konstitusi yang pertama, Konstitusi-konstitusi yang pernah digunakan di Indonesia, Hubungan dasar negara dengan konstitusi.

6) Kekuasan dan Politik, meliputi: Pemerintahan desa dan kecamatan, Pemerintahan daerah dan otonomi,
Pemerintah pusat, Demokrasi dan sistem politik, Budaya politik, Budaya demokrasi menuju masyarakat madani, Sistem pemerintahan, Pers dalam masyarakat demokrasi.

7) Pancasila meliputi: kedudukan Pancasila sebagai dasar negara dan ideologi negara, Proses perumusan Pancasila sebagai dasar negara, Pengamalan nilai-nilai Pancasila dalam kehidupan sehari-hari, Pancasila sebagai ideologi terbuka.

8) Globalisasi meliputi: Globalisasi di lingkungannya, Politik luar negeri Indonesia di era globalisasi, Dampak globalisasi, Hubungan internasional dan organisasi internasional, dan Mengevaluasi globalisasi.

Dari berbagai konsep dan substansi di atas, maka secara konseptual teoritik, substansi PKn dapat dikelompokkan menjadi komponen pokok yaitu civic knowledge (pengetahuan kewarganegaraan), civic skill (ketrampilan kewarganegaraan), civic disposition (karakter kewarganegaraan) (Branson, et al., 1999: 8-25).

Secara sederhana tujuan PKn adalah membentuk warga negara yang lebih baik ( $a$ good citizen) dan mempersiapkannya untuk masa depan. Rumusan itu, bersifat abstrak. Untuk menjabarkannya Secara konkret, banyak cara yang dapat dilakukan, antara lain dengan cara mengidentifikasi kualitas individu yang diharapkan dapat berprestasi, atau prinsipnya mengidentifikasi tentang manusia yang baik. Tetapi yang jelas ukuran warga negara yang baik untuk setiap bangsa/negara akan ditentukan oleh ukuran normatif yaitu ideologi dan konstitusi negara yang bersangkutan (Cholisin, 2007: 1.18).

Menurut Dimon \& Pflieger (1970:1617) dalam bukunya Civics for Citizens warga negara yang baik adalah yang memiliki ciri-ciri sebagai berikut:

1) The good citizen is loyal.

2) The good citizen practices democratic human relationships.

3) The good citizen tries to be a well-adjusted person.

4) The good citizen is a learner.

5) The good citizen is a thinker.

6) The good citizen is a doer.

National Council for the Social Studies (Dewan Nasional untuk Ilmu Pengetahuan Sosial) mengajukan tujuan PKn, yaitu: " .... to create citizens who are informed, analytic, committed to democratic values, and actively involved in society" (Robinson, 1967: 12). 
Artinya PKn bertujuan membuat warga negara yang paham informasi, analitis, melaksanakan nilai-nilai demokrasi dan berpartisipasi aktif di dalam masyarakat.

Kemudian

dalam usaha mengembangkan tujuan tersebut dirinci menjadi 11 tujuan, yaitu sebagai berikut:

1) Memiliki pengetahuan dan kecakapan memecahkan masalah (knowledge and skills for solving problems);

2) Memiliki kesadaran akan peranan kontemporer dari ilmu pengetahuan (awareness of the contemporary fole of science);

3) Memiliki kesiapan untuk kehidupan ekonomi yang efektifif (readiness for effective economic life);

4) Memiliki kemampuan mengambil keputusan-keputusan nilai terhadap dunia yang berubah-ubah (value judgments for a changing world);

5) Penerimaan terhadap fakta-fakta baru, gagasan-gagasan baru dan cara-cara hidup baru (receptivity to new facts, ideas, and ways of life);

6) Partisipasi dalam pembuatan keputusan (partisipation in decision making);

7) Meyakini akan asas persamaan dan kebebasan (belief in equality and liberty);

8) Menumbuhkan kebanggaan nasional dan semangat kerjasama internasional (national pride and international cooperation);

9) Menumbuhkan seni kreatif dan humanistik (the creative and humanistic awareness);

10) Menumbuhkan perasaan belas kasihan terhadap rakyat atau menumbuhkan pandangan yang bisa menghargai manusia sebagai manusia (a compassionate citizenry);

11) Pengembangan dan penerapan prinsipprinsip demokrasi (development and application of democratic principles).

Di Indonesia, mata pelajaran PKn berdasarkan KTSP 2006 bertujuan agar peserta didik memiliki kemampuan sebagai berikut.

1) Berpikir secara kritis, rasional, dan kreatif dalam menanggapi isu kewarganegaraan

2) Berpartisipasi secara aktif dan bertanggung jawab, dan bertindak secara cerdas dalam kegiatan bermasyarakat, berbangsa, dan bernegara, serta anti-korupsi

3) Berkembang secara positif dan demokratis untuk membentuk diri berdasarkan karakterkarakter masyarakat Indonesia agar dapat hidup bersama dengan bangsa-bangsa lainnya

4) Berinteraksi dengan bangsa-bangsa lain dalam percaturan dunia secara langsung atau tidak langsung dengan memanfaatkan teknologi informasi dan komunikasi.

\section{Efektivitas Penegakan Hukum HKI}

Berdasarkan hasil penelitian dapat diketahui bahwa penegakan hukum HKI di Indonesia masih belum efektif. Belum efektifnya penegakan hukum HKI dapat dilihat dari beberapa indikator nasional maupun internasional.

Indikator pertama adalah yang paling mudah dimana kita bisa melihat di sekitar kita para pedagang maupun pengedar barang bajakan dengan leluasa dan tanpa rasa takut menjajakan barang dagangannya. Mereka seolah menganggap pekerjaan mereka sebagai pekerjaan halal pada umumnya tanpa takut dituduh melanggar hukum atau kena penindakan dari petugas. Bahkan di wilayah Glodok Jakarta terdapat sebuah tempat penampungan dan distribusi distribusi jutaan/hari CD/VCD/DVD hasil tindak pidana Hak Cipta tanpa adanya upaya penindakan sesuai ketentuan hukum yang berlaku padahal diketahui bahwa tempat tersebut bersebelahan dengan Kantor Penegak Hukum (Penyidik) Polisi Resort Glodok. Menurut laporan dari ASIRI (Wawancara, 28/01/11), tempat ini bukan hanya tempat peredaran produk secara nasional akan tetapi saat ini bahkan telah menjadi tempat transit perdagangan produk ilegal secara Internasional (barang dari China dikirim ke Australia melalui Penampungan, Jalan Pinangsia Glodok, Jakarta).

Indikator kedua dapat dilihat dari laporan Asosiasi Industri Rekaman Indonesia (Asiri) serta Persatuan Artis Penyanyi, Pencipta Lagu dan Penata Musik Rekaman Indonesia (Pappri) yang menunjukkan bahwa pembajakan hak cipta bidang musik musik terus meningkat drastis dari tahun ke tahun sebagaimana dideskripsikan dalam Tabel 1. 
Tabel 1. Pembajakan Hak Cipta Musik

\begin{tabular}{|c|c|c|c|}
\hline Tahun & $\begin{array}{c}\text { Jumlah Lagu Bajakan } \\
\text { (Keping) }\end{array}$ & $\begin{array}{c}\text { Kerugian Pemegang Hak } \\
\text { Cipta (Rp) }\end{array}$ & $\begin{array}{c}\text { Kerugian Negara } \\
\text { (Rp) }\end{array}$ \\
\hline 2005 & 359.204 & 12,975 triliun & 934,083 juta \\
\hline 2006 & 385.701 .129 & 13,330 triliun & 974,245 juta \\
\hline 2007 & 443.556 .298 & 15,358 triliun & 1,122 triliun \\
\hline 2008 & \pm 500 juta & \pm 16 triliun & 1,2 triliun \\
\hline 2009 & \pm 560 juta & \pm 17 triliun & 2,5 triliun \\
\hline
\end{tabular}

Sumber: Asiri, 2009; Pappri, 2009; Bisnis.com, 2009 (data diolah)

Indikator ketiga dapat dilihat dari hasil studi tahun ke-6 International Data Corporation (IDC) tentang Global Software Piracy Study 2008 yang melaporkan bahwa tingkat pembajakan di Indonesia sudah mencapai 85 persen. Artinya dari 100 komputer, 85 diantaranya berindikasi di-install dengan software ilegal atau tidak berlisensi (Hukumonline, 12/5/09). Bahkan dalam wawancara (26/01/11) dengan Konsultan Hukum $B S A$, Justisiari $\mathrm{P}$. Kusumah dinyatakan bahwa angka pembajakan tahun 2010 justru naik menjadi 86 persen.

Indikator keempat untuk melihat belum berhasilnya penegakan hukum HKI di Indonesia dapat dilihat dari laporan International Intellectual Property Rights Alliance (IIPA) dan United States Trade Representative (USTR). Pada tahun 2010, Indonesia masih berstatus sebagai "priority watch list" (Bisnis Indonesia, 05/05/10). Artinya, tingkat pembajakan di Indonesia masih tinggi, sehingga perlu mendapat pengawasan khusus oleh mitra dagangnya.

Indikator kelima tentang belum berhasilnya penegakan hukum HKI juga dapat dilihat dari survei lembaga Political and Economic Risk Consultancy (PERC) yang berbasis di Hongkong. Pada survei 2010, PERC melaporkan bahwa Indonesia memiliki catatan terburuk dalam melindungi HKI. Tingkat pembajakan di Indonesia masih termasuk yang tertinggi di dunia sebagaimana dideskripsikan dalam Tabel 2.

Tabel 2. Peringkat Pembajakan HKI

\begin{tabular}{|c|l|c|}
\hline Perigkat & \multicolumn{1}{|c|}{ Negara } & Skor \\
\hline 1 & Indonesia & 8,5 \\
\hline 2 & Vietnam & 8,4 \\
\hline 3 & China & 7,9 \\
\hline 4 & Filipina & 6,84 \\
\hline 5 & India & 6,5 \\
\hline 6 & Thailand & 6,17 \\
\hline
\end{tabular}

Yustisia Vol.1 No.2 Mei - Agustus 2012

\begin{tabular}{|c|l|c|}
\hline 7 & Malaysia & 5,8 \\
\hline 8 & Korea Selatan & 4,1 \\
\hline 9 & Taiwan & 3,8 \\
\hline 10 & Hongkong & 2,8 \\
\hline 11 & Jepang & 2,1 \\
\hline 12 & Singapura & 1,5 \\
\hline
\end{tabular}

Sumber: Survei PERC Juni-Agustus 2010 (Antara, 25/08/10)

Berdasarkan hasil penelitian dapat diketahui bahwa penegakan hukum HKI di Indonesia masih mengalami beberapa kendala yang disebabkan oleh beberapa faktor sebagai berikut:
a. Rendahnya tingkat pemahaman HKI masyarakat Indonesia.
b. Rendahnya kesadaran (hukum) HKI masyarakat Indonesia.
c. Perbedaan kultur HKI dengan kultur masyarakat Indonesia.
d. Belum seimbangnya kegiatan pre-emtif, preventif dan represif.
e. Perbedaan penafsiran peraturan oleh para penegak hukum.
f. Terbatasnya pengetahuan HKI penegak hukum.
g. Terbatasnya sarana prasarana penegak hukum.
h. Belum profesionalnya kerja aparat penegak hukum.
i. Ringannya vonis yang diberikan terhadap pelanggar HKI.
j. Kurangnya transparansi bisnis antara pencipta/artis dan produser
k. Belum maksimalnya kinerja Timnas HKI.

Dengan mengacu pada pendapat Friedman (2001: 7) tentang efektivitas penegakan hukum, maka berbagai faktor di atas dapat dikelompokkan menjadi tiga bagian yaitu faktor substansi, faktor struktural, dan faktor kultural. 


\section{a. Faktor Subtansi}

Subtansi adalah aturan, norma, dan pola perilaku nyata manusia yang berada dalam sistem itu. Substansi berarti produk yang dihasilkan oleh orang yang berada di dalam sistem hukum itu, keputusan atau aturan baru yang mereka keluarkan.

Secara umum Indonesia telah mempunyai regulasi HKI yang baik. Kesulitan biasanya terletak pada hal pembuktian pada saat penyidikan maupun di pengadilan. Misalnya sebagaimana disampaikan oleh Penyidik HKI Mabes Polri Kompol Pratomo Satriawan, SIK, (Wawancara, 26/01/11), apabila ada kasus pembajakan software microsoft apakah harus menghadirkan Penciptanya asli (Bill Gates) atau cukup pemegang kuasanya di Indonesia $(B S A)$. Pernah suatu ketika jaksa meminta agar penyidik memeriksa Bill Gates. Hal ini tentu sulit dilakukan apabila belum ada persamaan pemahaman antarpenegak hukum.

Indonesia dapat dikatakan telah memiliki perangkat ketentuan yang memadai. Ada tujuh undang-undang yang berkaitan dengan perlindungan $\mathrm{HKI}$, masing-masing UndangUndang (UU) tentang Hak Cipta (Copyright), UU Paten (Patent) dan Merek (Trademark), UU Desain Industri (Industrial Design), UU Rahasia Dagang (Trade Secret), UU Desain Tata Letak Sirkuit Terpadu (Design of Circuit Layout), dan UU Perlindungan Varietas Tanaman.

Soal hukuman, bagi pembajak yang melanggar undang-undang telah diancam dengan hukuman berat dan denda yang tinggi. Dan mengenai prosedur penyidangan perkara/ gugatan merek dan hak cipta juga memakan waktu yang relatif singkat (lebih kurang 6 bulan sampai putusan Mahkamah Agung) karena diperlakukannya Pengadilan Niaga. Adanya upaya hukum penetapan sementara (injunction action) dari pengadilan untuk mencegah kerugian lebih besar bagi pemilik merek/hak cipta dengan menghentikan produksi bajakan juga menunjukan adanya kemajuan dalam penegakan hukum.

Meskipun sarana hukum telah baik namun pelaksanaan kembali kepada para penegak hukum apakah ada kemauan untuk menindak para pembajak. Konsekuensi lemahnya penegakan hukum di bidang HKI membuat bangsa ini hanya menjadi bangsa yang konsumeris. Lebih jauh lagi, bangsa ini hanya menjadi bangsa pengguna, bukannya pencipta.

\section{b. Faktor Struktural}

Struktur adalah kerangka atau bagian yang tetap bertahan, bagian yang memberi semacam bentuk dan batasan terhadap keseluruhan sistem. Struktur penegakan hukum mencakup kepolisian, kejaksaan, kehakiman, advokat, lembaga peradilan dan pemasyarakatan.

Faktor aparat berperan vital dalam penegakan hukum HKI. Pemahaman dan profesionalitas serta sarana-prasarana aparat berperan besar dalam mendukung efektivitas penegakan HKI. Hasil penelitian menunjukkan belum banyak aparat hukum terutama di daerahdaerah yang paham tentang seluk beluk HKI. Profesionalitas aparat juga menjadi pertanyaan ketika terjadi kesepakatan 'damai' antara aparat dan pelaku pembajakan yang ditangani.

Sarana-prasarana menjadi penting bagi aparat untuk menentukan barang bukti yang disita adalah produk bajakan. Mengigat tidak mudah membedakan antara produk asli dengan produk bajakan. Saat ini laboratorium untuk menentukan barang asli atau bajakan hanya terdapat di Mabes Polri sementara di daerahdaerah belum tersedia. Dampaknya, aparat daerah menjadi enggan untuk menangani kasus pelanggaran HKI. Kalaupun menangani maka cenderung terjadi kesepakatan 'damai' antara aparat dengan pembajak.

Pembentukan Timnas HKI telah membawa citra positif bagi Indonesia di mata internasional. Akan tetapi keberadaan Timnas HKI juga tidak lepas dari kekurangan atau kelemahan. Apabila dicermati, kegiatan-kegiatan yang dilakukan Timnas HKI kesemuanya diperuntukan bagi masyarakat dewasa. Padahal, salah satu akar masalah pelanggaran HKI terletak pada karakter seseorang. Pendidikan karakter anti pembajakan hanya efektif apabila dilakukan sejak usia dini. Oleh karenanya kegiatan-kegiatan Timnas HKI di atas hingga saat ini belum efektif untuk menekan pembajakan HKI.

\section{c. Faktor Kultural}

Kultur atau budaya merupakan sikap manusia terhadap hukum dan sistem hukum, kepercayaan, nilai, pemikiran serta harapannya. Budaya HKI berasal dari semangat eksklusivitas individu. Faktor budaya ini bisa dilihat dari bebarapa sisi antara lain budaya masyarakat itu sendiri, pemahaman masyarakat terhadap hukum, dan pola pikir masyarakat terhadap HKI.

Budaya HKI yang bersifat eksklusif dan individual bertolak belakang dengan budaya sebagian masyarakat Indonesia yang berbudaya komunal. Sebagaimana dikemukakan oleh Guru 
Besar Ilmu HKI Universitas Indonesia Prof. Agus Sardjono (Wawancara, 25/01/11) bahwa dalam masyarakat kita dikenal filosofi "berbagi" yang bertentangan dengan filosofi HKI yang eksklusif dan individual. Hal ini menyebabkan penegakan hukum HKI menjadi tidak efektif.

Penegakan hukum HKI juga bermasalah ketika masyarakat hanya memahami hukum sebagai perilaku aparat. Menurut Prof. Soerjono Soekanto (1993: 14), terdapat kecenderungan yang besar pada masyarakat, untuk mengartikan hukum dan bahkan mengidentifikasiknnya dengan petugas atau penegak hukum secara pribadi. Oleh karenanya, para pembajak hanya takut pada saat ada rasia, penggrebekan, penyitaan, maupun penangkapan yang bersifat musiman. Pada saat ada penindakan mereka 'tiarap' setelah selesai penindakan maka mereka akan kembali menjual barang bajakan lagi. Bahkan hal ini diperparah dengan perilaku aparat yang tidak profesional dengan membuat kesepakatan 'damai' dengan pembajak. Padahal menurut teori hukum, kesepakatan damai hanya diperbolehkan dalam perkara perdata sementara pembajakan adalah pelanggaran pidana.

Saat ini masyarakat belum menganggap pelanggaran HKI sebagai kejahatan serius dibanding kejahatan lain seperti pencurian atau pembunuhan. Pandangan masyarakat ini menyebabkan masyarakat kurang peduli dengan pelanggaran HKI. Pandangan awam ini bisa dipahami karena dalam pelanggaran HKI tidak ada korban secara langsung. Sehingga masyarakat menilai pembajakan tidaklah merugikan tetapi justru 'menguntungkan' karena masyarakat bisa memperoleh barang dengan mudah dan murah. Pandangan masyarakat ini juga disampaikan oleh Penyidik HKI dari Mabes Polri, Kompol. Pratomo Satriawan, SIK, (Wawancara, 26/01/11) yang menyatakan bahwa "Para pembajak sering bilang bahwa perbuatan mereka tidak merugikan siapapun, Nah merubah mindset ini yang susah", katanya.

Di sisi lain, pembahasan tentang HKI hanya didomimasi oleh pendekatan hukum dan ekonomi. Hal inilah yang menyebabkan muncul berbagai pandangan negatif tentang HKI. Misalnya penegakan HKI dianggap 'pesanan' dari negara-negara/perusahaan-perusahaan barat. Penegakan HKI juga dianggap sebagai bentuk baru dari kolonialisme barat dan lain-lain. Padahal dalam HKI terdapat banyak nilai nilai (values) positif yang perlu dikembangkan dalam kehidupan sehari-sehari seperti kejujuran, kreativitas, penghormatan dan penghargaan terhadap karya orang lain, serta bangga terhadap karya sendiri. Nilai-nilai universal inilah yang perlu kita bahas dalam HKI sebelum membahas dari sisi hukum, sisi ekonomi apalagi masalah royalti. Apabila masyarakat sudah paham dengan nilai-nilai HKI maka dengan sendirinya akan memahami HKI secara hukum maupun ekonomi.

\section{Urgensi Pendidikan Kesadaran HKI}

Hasil penelitian menunjukkan bahwa penegakan hukum HKI tidak cukup dilakukan dengan pendekatan represif semata karena berbagai kegiatan penindakan yang telah dilakukan ternyata belum berhasil menekan pelanggaran HKI secara signifikan. Tindakan represif juga bukanlah solusi utama dalam penanggulangan pelanggaran HKI karena tidak menyentuh akar persoalan. Oleh karenanya para akademisi maupun praktisi sepakat bahwa perlu dilakukan penguatan penegakan hukum HKI melalui upaya pendidikan.

Menurut Prof. Agus Sardjono, saat ini belum ada keseimbangan antara tindakan preemtif, preventif dan represif. Aspek pendidikan HKI masih belum di perhatikan sebagai diungkapkannya bahwa:

"Pendidikan masih sangat kurang,
jangankan SD, SMP, SMA, di
Perguruan Tinggi saja yang
menawarkan mata kuliah HKI sangat
sedikit, sekarang yang ada program
magister HKI baru UI, yang lain belum
ada, swasta ada tapi saya rasa gak
serius itu. " (Agus Sardjono,
Wawancara, 25/01/11).

Justisiari P. Kusumah selaku konsultan HKI juga melihat character building dalam pendidikan HKI sangat penting. Menurutnya, tindakan represif memang diperlukan, tetapi sesungguhnya itu hanya kegiatan hilir saja. Karena apabila kegiatan hulunya tidak dibahas maka penegakan HKI juga tidak akan efektif sebagaimana diungkapkannya sebagai berikut:

"Selain represif, character building itu juga paling penting. Karena kalau kita hanya melihat di ujung-ujung saja, ada pelanggaran kita pukul, ada lagi kita pukul lagi, sementara diperjalanan sebelumnya mereka tidak tahu bahwa tindakan mereka merupakan suatu pelanggaran karena kurangnya sosialisasi, tapi kemudian sosialisasi tidak diperlukan lagi kalau dari sisi 
dasarnya sudah ditanamkan bahwa anda harus menghargai HKI sehingga character building sangat penting. Kalau kita ingin efektif tidak bisa cuma represif. Character bulding penting dan harus dimulai dari awal, sejak dini kita mulai hargai, ketika anak kita menggambarnya bagus kita bilang jangan dicontek ya, jangan njiplak terus kamu bilang itu gambar kamu. Itu mulai kita bangunkan karakter-karakter semancam itu". (Justisiari, Wawancara, 26/01/11).

Pihak kepolisian juga mengakui pentingnya pendidikan HKI bagi anak usia dini. Hal ini diungkapkan oleh Penyidik HKI Mabes Polri Kompol Pratomo Satriawan, SIK., yang menyatakan bahwa:

"Mestinya sejak SD sudah diberikan pelajaran (pendidikan) HKI. Jadi begitu kita melakukan penindakan di lapangan tidak ada perlawanan dari masyarakat. Karena mereka melawan itu karena gak tahu, merasa tidak bersalah atau tidak mencuri. Karena masih banyak orang berpendapat bahwa membajak karya cipta bukan suatu kejahatan yang serius, karena memang kejahatan ini tidak ada korban secara langsung, bahkan dianggap menguntungkan masyarakat karena bisa membeli barang dengan harga murah. Tetapi sebenarnya itu kan instan saja. Nah membentuk mindset masyarakat itu yang susah" (Kompol Pratomo Wawancara, 26/01/11).

Dalam sebuah diskusi antara peneliti dengan Direktur Kerjasama DJHKI Drs. Moh. Adri, SH. dan Juru Bicara BSA Donny Sheyoputra, SH.LLM, bertempat di DJHKI (25/01/11), diperoleh kesimpulan bahwa pendekatan represif penting tetapi porsinya lebih sedikit ketimbang pendekatan pre-emtif dan preventif. Bapak Adri menyatakan bahwa "mestinya pendekatan pre-emtif dan represif perlu dilakukan sehingga cara-cara penangkapan, penggrebekan dan sejenisnya tidak perlu dilakukan".

Pihak ASIRI yang diwakili General Manager-nya Marulam J. Hutauruk, SH. juga mengakui bahwa pendidikan karakter dalam HKI sangat penting sekali diterapkan sejak anak usia dini sebagaimana dinyatakannya sebagai berikut:
"Pendidikan karakter sangat penting sekali. Karakter dan nilai eksistensi manusia adalah sangat penting. Menurut pendapat kami, nilai ini harus ditanamkan sejak usia dini bahkan sejak dalam kandungan. Bagaimana caranya? Dengan perkataan-perkataan orang tua saat berkomunikasi dengan jabang bayi dengan memperkatakan bahwa jabang bayi tersebut memiliki eksistensi yang luar biasa dengan sifat-sifat yang luar biasa yang berasal dari Tuhan sendiri. Kemudian pada usia sekolah TK, SD, SMP bahkan SMA dan perguruan tinggi sangat memerlukan program-program yang menghargai inventions. Kami setuju dengan programprogram invention week di Jepang akan tetapi yang harus dikedepankan adalah penghargaan atas apapun yang telah diciptakan dan seberapa berguna ciptaan itu bagi kemaslahatan orang banyak" (Marulam, Wawancara, 28/01/11).

\section{Peran PKn dalam Penguatan Penegakan Hukum HKI \\ a. PKn sebagai Wahana Pendidikan Karakter \\ Pendidikan kewarganegaaan} (citizenship education) mencakup berbagai kajian seperti citizenship, civics, ilmu pengetahuan sosial, life skills, dan pendidikan moral, sejarah, geografi, ekonomi, hukum, politik, lingkungan hidup, dan pendidikan nilai (Kerr, 1999: 2). Citizenship education merupakan topik utama di banyak negara saat ini karena menjadi pendekatan baru dan pertimbangan penting yang harus diberikan untuk mempersiapkan generasi muda menghadapi tantangan dan ketidakpastian perubahan dunia (Ichilov, 1998: 39).

Pendidikan kewarganegaraan (PKn) pada hakikatnya merupakan pendidikan yang mengarah pada terbentuknya warga negara yang baik dan bertanggung jawab. Secara konseptualepistemologis, PKn dapat dilihat sebagai suatu integrated knowledge system (Hartoonian, 1992: 160-163) yang memiliki misi menumbuhkan potensi peserta didik agar memiliki pengetahuan, sikap, dan ketrampilan sebagai warga negara yang berwatak dan berperadaban baik (Winataputra, 2001: 131). Pendidikan

kewarganearaan (citizenship education) dan pendidikan karakter (character education) merupakan dua hal yang 
berkaitan erat sehingga muncul istilah character and citizenship education. PKn dan pendidikan karakter merupakan suatu konsep inklusif yang membahas segala aspek tentang bagaimana lingkungan sekolah dapat mendukung pengembangan karakter positif terhadap siswa, staf, dan para stakeholders. Semua kegiatan ini tercermin dalam semua kegiatan sekolah dalam bentuk kurikulum, tata tertib, maupun kegiatan ekstrakurikuler. Semua sekolah telah menerapkan pendidikan karakter meskipun tidak secara eksplisit disebut pendidikan karakter (Alberta School, 2005: 2).

Pendidikan kewarganegaraan merupakan suatu bentuk pendidikan karakter yang mengajarkan etika personal dan nilai-nilai kebaikan (Best, 1960: Winataputra, 2001: 127). Pendidikan kewarganegaraan juga merupakan sebuah proses untuk membentuk karakter individu sebagai warga negara yang baik dan cerdas atau smart and good citizen (Cogan and Derricot, 1998: 2). Pendidikan kewarganegaraan merupakan program pendidikan yang dapat dijadikan sebagai sarana pembangunan karakter bangsa atau nation character building (Sapriya, 2005: 4). Pendidikan karakter tidak mungkin dipisahkan dari dari sistem pembelajaran yang ada di sekolah itu sendiri. Permasalahannya adalah adanya kesulitan seorang pendidik untuk secara efektif mengembangkan karakter positif kepada siswanya (Williams, 2000: 34).

Salah satu unsur dari budaya kewarganegaraan adalah "civic virtue" (kebajikan/ akhlak kewarganegaraan) yang terpancar dari nilai-nilai PKn yang mencakup keterlibatan aktif warga negara, hubungan kesejajaran/egaliter, saling percaya dan toleran, saling menghormati dan menghargai; kehidupan yang kooperatif, solidaritas, dan semangat kemasyarakatan. Semua unsur akhlak kewarganegaraan itu diyakini akan saling memupuk dengan kehidupan "civic community" atau "civil society" atau masyarakat madani. Artinya, tumbuh dan berkembangnya akhlak kewarganegaraan (civic virtue) merupakan unsur utama dari budaya kewarganegaraan atau civic culture (Depdiknas, 2007: 7).

Perubahan atribut warga negara atau karakter warga negara yang diinginkan jelas amat menentukan bagi perubahan konsep pendidikan kewarganegaraan sebagaimana telah disampaikan sebelumnya. Karakter warga negara Indonesia yang hendak dibentuk dipengaruhi oleh kepentingan hidup berbangsa dan bernegara sesuai dengan zamannya. Cerminan dari karakter warga negara Indonesia tampak dalam rumusan tujuan pendidikan nasional. Dalam UU Sisdiknas dirumuskan sejumlah tujuan pendidikan nasional yang pada hakekatnya menunjuk pada sejumlah karakter warga negara yang diinginkan. Pasal 3 UU Sisdiknas menyatakan bahwa pendidikan nasional berfungsi mengembangkan kemampuan dan membentuk watak serta peradaban bangsa yang bermartabat dalam rangka mencerdaskan kehidupan bangsa, bertujuan untuk berkembangnya potensi peserta didik agar menjadi manusia yang beriman dan bertakwa kepada Tuhan Yang Maha Esa, berakhlak mulia, sehat, berilmu, cakap, kreatif, mandiri, dan menjadi warga negara yang demokratis serta bertanggung jawab.

\section{b. Peran PKn sebagai Pendidikan HKI}

Secara konseptual teoritik, PKn yang bermutu mengharuskan tiga komponen pokok yaitu civic knowledge (pengetahuan kewarganegaraan), civic skill (ketrampilan kewarganegaraan), civic disposition (karakter kewarganegaraan) (Branson, et al., 1999: 8-25).

\section{1) Civic Knowledge}

Pengetahuan kewarganegaraan (civic knowledge) merupakan materi subtansi yang harus diketahui oleh warga negara. Pada prinsipnya pengetahuan yang harus diketahui warga negara berkaitan dengan hak dan kewajiban/peran sebagai warga negara. Dalam pembelajaran, civic knowledge dikategorikan sebagai kemampuan kognitif.

Dalam konteks pendidikan HKI, civic knowledge dapat menekankan pada perlunya pemahaman tentang pengertian HKI, peraturan HKI dan tujuan perlindungan HKI. Apabila masyarakat paham akan pengertian, peraturan dan tujuan perlindungan HKI maka diharapkan mereka tidak akan melakukan pelanggaran HKI. Civic knowledge dapat dimulai pada jenjang SMA.

\section{2) Civic Skill}

$\begin{array}{llr}\text { Ketrampilan } & \text { kewarganegaraan (civic } \\ \text { skill), merupakan ketrampilan yang } \\ \text { dikembangkan } & \text { dari pengetahuan }\end{array}$ kewarganegaraan, agar pengetahuan yang diperoleh menjadi sesuatu yang bermakna, karena dapat dimanfaatkan dalam menghadapi masalah-masalah kehidupan berbangsa dan bernegara. Civic skill mencakup intellectual skill (ketrampilan intelektual) dan participation skill (ketrampilan partisipasi). Dalam pembelajaran, civic skill dikategorikan sebagai kemampuan psikomotorik. 
Dalam konteks pendidikan HKI, civic skills mencakup ketrampilan dalam memanfaatkan sistem HKI seperti tata cara pendaftaran dan perpanjangan, mengajukan keberatan/gugatan atau berperkara di pengadilan. Pengetahuan tentang HKI saja tidaklah cukup apabila belum mempunyai ketrampilan HKI. Civic skill lebih baik apabila diterapkan di tingkat perguruan tinggi sebagaimana sudah dilakukan di berbagai fakultas hukum yang menerapkan mata kuliah HKI.

\section{3) Civic Disposition}

Karakter kewarganegaraan (civic disposition), merupakan sifat-sifat yang harus dimiliki setiap warga negara demi terjaganya martabat, harga diri dan kepentingan umum. Meskipun seseorang sudah memiliki pengetahuan dan ketrampilan yang baik, akan tetapi dapat menjadi jahat apabila tidak mempunyai karakter dan mental yang baik. Dalam pembelajaran, civic disposition dikategorikan sebagai kemampuan afektif.

Dalam konteks pendidikan HKI, civic disposition mencakup nilai-nilai moral yang perlu ditransfer kepada anak usia dini yaitu kejujuran, kreativitas, serta penghormatan dan penghargaan terhadap karya orang lain. Nilainilai inilah yang menjadi 'ruh' dari pendidikan
HKI sebelum pembicaraan HKI dibahas dengan pendekatan hukum dan ekonomi. Civic disposition lebih tepat apabila diterapkan pada jenjang TK-SD-SMP karena pada usia inilah masa pembentukan karakter dasar anak.

Pendidikan HKI yang dilakukan selama ini belum menyentuh aspek karakter. Sebagian besar pelaku pelanggar HKI adalah orang yang mempunyai pendidikan tinggi dan mengetahui bahwa pembajakan merupakan perbuatan melanggar hukum. Akan tetapi, karena mental dan karakternya tidak baik maka mereka justru menjadi pelanggar HKI tingkat tinggi.

Pendidikan HKI diharapkan dapat menciptakan warga negara dengan tiga kompetensi di atas. Program Timnas HKI belum menyentuh aspek pendidikan karakter bagi anak usia dini. Sementara itu IIPA (Indonesian Intellectual Property Academy) yang selenggarakan oleh UI baru sebatas memberi bekal pengetahuan dan ketrampilan tentang HKI. Sedangkan untuk aspek karakter belum memperoleh perhatian yang seimbang. Orang yang mempunyai tiga kompetensi di atas diharapkan dapat menjadi pribadi yang memiliki pengetahuan, ketrampilan dan karakter tentang HKI. Keterkaitan ketiga kompetensi tadi dapat dilihat dalam diagram sebagai berikut:

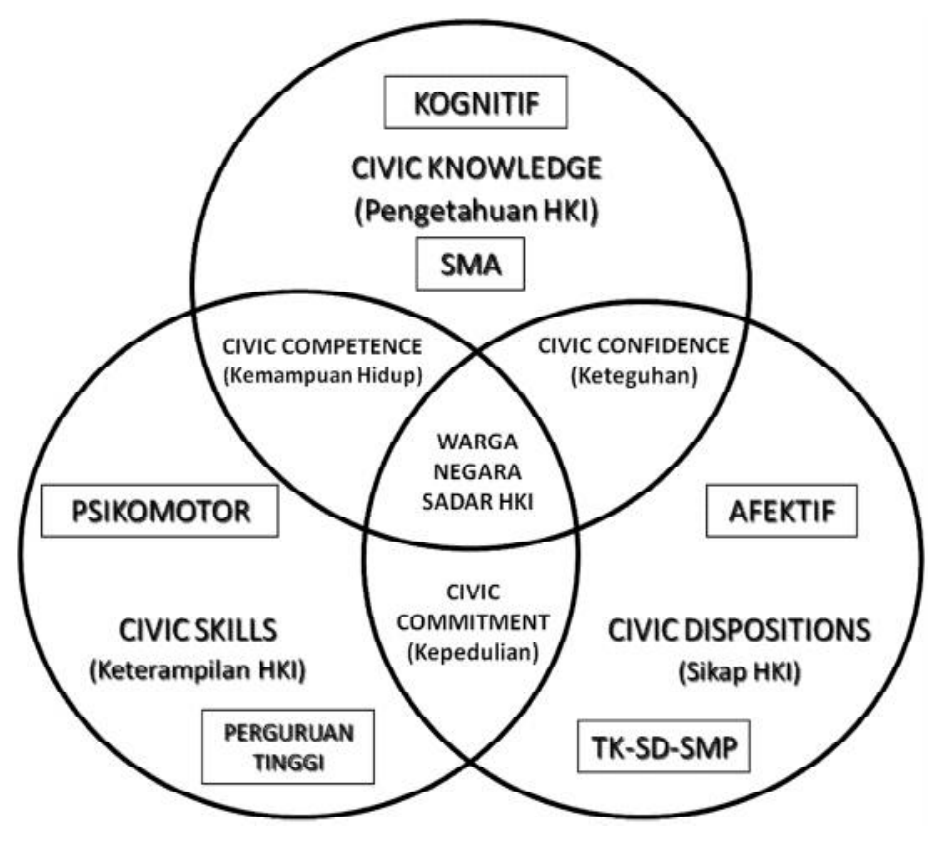

Bagan 1. Integrasi tiga kompetensi warga negara untuk pendidikan HKI

(Dimodifikasi dari Model PKn CCE, 2009) 
Prinsip utama dari perlindungan HKI adalah kejujuran, penghormatan dan penghargaan terhadap hak orang lain. Prinsip saling menghormati dan menghargai antar sesama (hak) warga negara merupakan salah satu nilai/ ajaran yang fundamental dalam PKn. Jadi, prinsip-prinsip kesadaran hukum atas HKI sudah ada dalam substansi PKn di Indonesia sehingga dapat dimanfaatkan sebagai wahana pendidikan kesadaran HKI.

Pendidikan kewarganegaraan (PKn) dan pendidikan karakter merupakan dua hal yang berkaitan erat. PKn merupakan suatu bentuk pendidikan karakter yang mengajarkan etika pribadi dan nilai-nilai kebajikan/akhlak kewarganegaraan (civic virtue). PKn merupakan suatu proses untuk membentuk warga negara yang baik dan cerdas (smart and good citizen). Salah satu bentuk civic virtue yaitu sikap jujur, saling menghormati dan menghargai orang lain. Sikap jujur, penghormatan dan penghargaan terhadap karya orang lain merupakan ajaran fundamental dalam pendidikan kesadaran HKI. Kesimpulannya, PKn dapat dijadikan sebagai wahana pendidikan karakter sadar HKI melalui penanamam nilai-nilai kejujuran, penghormatan dan penghargaan terhadap karya orang lain. Penanaman nilai-nilai tersebut dapat dilakukan melalui PKn persekolahan (civic school) maupun PKn berbasis kemasyarakatan (community-based citizenship education).

\section{Simpulan}

Penegakan hukum HKI di Indonesia belum efektif terlihat dengan beberapa indikator yaitu: (1) masih maraknya peredaran produk bajakan di sekitar kita; (2) meningkatnya angka pembajakan sebagaimana dilaporkan pelaku industri dan data penegak hukum; (3) laporan USTR 2010 yang menempatkan Indonesia sebagai "priority watch list"; (4) survei lembaga PERC yang menempatkan Indonesia sebagai pembajak terbesar di dunia.

Penegakan hukum HKI di Indonesia masih mengalami beberapa kendala yang disebabkan oleh beberapa faktor sebagai berikut:

1. Rendahnya tingkat pemahaman HKI masyarakat Indonesia.
2. Rendahnya kesadaran (hukum) HKI masyarakat Indonesia.

3. Perbedaan kultur HKI dengan kultur masyarakat Indonesia.

4. Belum seimbangnya kegiatan pre-emtif, preventif dan represif.

5. Perbedaan penafsiran peraturan oleh para penegak hukum.

6. Terbatasnya pengetahuan HKI penegak hukum.

7. Terbatasnya sarana prasarana penegak hukum.

8. Belum profesionalnya kerja aparat penegak hukum.

9. Ringannya vonis yang diberikan terhadap pelanggar HKI.

10. Kurangnya transparansi bisnis antara pencipta/artis dan produser

11. Belum maksimalnya kinerja Timnas HKI. Prinsip utama dari perlindungan HKI adalah kejujuran, penghormatan dan penghargaan terhadap hak orang lain. Prinsip saling menghormati dan menghargai antar sesama (hak) warga negara merupakan salah satu nilai/ajaran yang fundamental dalam PKn. Kesimpulannya, PKn dapat dijadikan sebagai wahana pendidikan HKI melalui penanaman nilai-nilai kejujuran, penghormatan dan penghargaan terhadap karya orang lain.

\section{E. Saran}

Berdasarkan simpulan di atas, maka dikemukankanlah saran-saran sebagai berikut:

1. Upaya penanggulangan pelanggaran HKI perlu dilakukan dengan pendekatan pendidikan bagi anak usia dini terutama menekankan pada pendidikan karakter tentang kesadaran HKI mengingat salah satu akar masalah pembajakan HKI adalah lemahnya karakter/mental masyarakat.

2. Kepada Kementerian Pendidikan Nasional perlu segera dipertimbangkan adanya muatan nilai-nilai HKI dalam kurikulum persekolahan khususnya jenjang usia dini.

3. Kepada para guru PKn di jenjang pendidikan dasar dapat menanamkan nilainilai HKI secara umum seperti kreativitas, kejujuran, penghormatan dan penghargaan terhadap hak (HKI) orang lain serta bangga dengan hasil karya sendiri. 


\section{Daftar Pustaka}

Alberta School. 2005. The Heart of the Mater: Character and Citizenship Education in Alberta Schools. Edmonton, Alberta: Alberta Education

Allen, J. 1960. "The Role of Ninth Grade Civics in Citizenship Education”, the High School Journal. Vol. 44,3 ; p.106-111.

Asshiddiqie, J. 2008. Peran Advokat Dalam Penegakan Hukum. Bahan Orasi Hukum pada acara "Pelantikan DPP IPHI Masa Bakti 2007 - 2012". Bandung, 19 Januari 2008.

Bisnis.com. 2009. Asiri rugi Rp15 Triliun Akibat Pembajakan. Jakarta: Senin, 02/02/2009

Branson, M.S. et al., 1999. Belajar Civic Education dari Amerika. Yogyakarta: Kerjasama LKIS dan The Asia Foundation.

Cholisin, et al., 2007. Ilmu Kewarganegaraan. Jakarta: Penerbit Universitas Terbuka.

Citizenship Foundation. (2010). "What is citizenship education?". Available in: http://www.citizenshipfoundation.org di akses tanggal 14 Desember 2010.

Cogan, J.J. and Derricott,R. 1998. Citizenship for the 21st Century, An International Perspective on Education. London: Kogan Page Limited.

Creswell, J.W. 2008. Educational Research: Planning, Conducting, and Evaluating Quantitative and Qualitative Research, Third Edition. USA: Edwards Brothers

Friedman, L.M. 2001. American Law, An Introduction. Jakarta: PT Tata Nusa.

Lincoln, YS and Guba. 1985. Naturalistic Inquiry. Beverly Hills CA: Sage Publications

Manan, B. (2005). "Penegakan Hukum yang Berkeadilan", Majalah Varia Peradilan No. 241 Nopember 2005, Ikahi, Jakarta

Marpaung, L. 1997. Tindak Pidana Lingkungan Hidup dan Masalah Prevensinya. Jakarta: Sinar Grafika

Miles, M.B. and Huberman, A.M. 1984. Qualitative Data Analysis, A Sourcebook of New Methods. Beverly Hills CA: Sage Publications Inc.

Muladi. 1995. Kapita Selekta Sistem Peradilan Pidana. Semarang: UNDIP Press

Rahardjo, S. 1998. Masalah Penegakan Hukum: Suatu Tinjauan Sosiologis. Bandung: Sinar Baru

Rahardjo, S. 2009. Penegakan Hukum, Suatu Tinjauan Sosiologis. Yogyakarta: Genta Publishing

Raharjo, S. 2002. Sosoilogi Hukum Perkembangan Metode Dan Pilihan Masalah. Surakarta: Muhamadiyah University Press.

Riswandi, B.A dan Syamsudin, M. 2005. Hak Kekayaan Intelektual dan Budaya Hukum. Jakarta: PT Raja Grafindo Persada.

Sapriya. 2005. Perspektif Pakar terhadap Pendidikan Kewarganegaraan sebagai Wahana Pembangunan Karakter Bangsa (Disertasi). Bandung: SPs UPI. 
Soekanto, S. 1993. Faktor-Faktor yang Mempengaruhi Penegakan Hukum. Jakarta: PT Raja Grafindo Persada

Somantri, N. 1973. Metode Pengajaran Civics. Bandung: IKIP Bandung.

Teachernet. 2010. "Citizenship". Available in: http://www.teachernet. gov.uk/diakses tanggal 14 Desember 2010.

The House of Commons. 2006. Citizenship Education, second report of session 2006-07. London: The Stationery Office Limited

Winataputra, U.S. 2001. Jatidiri Pendidikan Kewarganegaraan sebagai Wahana Pendidikan Demokrasi, (Disertasi). Bandung: UPI 